\title{
Treatment of osteoporosis with eldecalcitol, a new vitamin $D$ analog: a comprehensive review and meta-analysis of randomized clinical trials [Corrigendum]
}

Xu Z, Fan C, Zhao X, Tao H. Drug Des Devel Ther. 2016; 10:509-517.

The authors wish to advise that article type was incorrectly titled as a "Review" paper. The article type should be corrected as an "Original Research" paper.

Drug Design, Development and Therapy is an international, peerreviewed open-access journal that spans the spectrum of drug design and development through to clinical applications. Clinical outcomes, patient safety, and programs for the development and effective, safe, and sustained use of medicines are a feature of the journal, which has also been accepted for indexing on PubMed Central. The manuscript management system is completely online and includes a very quick and fair peer-review system, which is all easy to use. Visit http://www.dovepress.com/testimonials.php to read real quotes from published authors.

Submit your manuscript here: http://www.dovepress.com/drug-design-development-and-therapy-journal 